\title{
Molecular basis of cellulose biosynthesis disappearance in submerged culture of Acetobacter xylinum ${ }^{\star}$
}

\author{
Alina Krystynowicz ${ }^{1}$, Maria Koziołkiewicz ${ }^{1}$, Agnieszka Wiktorowska-Jezierska1, \\ Stanisław Bielecki ${ }^{1 凶}$, Emilia Klemenska ${ }^{2}$, Aleksander Masny $^{2}$ and \\ Andrzej Płucienniczak ${ }^{2}$
}

${ }^{1}$ Institute of Technical Biochemistry, Technical University of Lodz, Eódź, Poland; ${ }^{2}$ Institute of Biotechnology and Antibiotics, Warszawa, Poland; ${ }^{-}$-mail: stanb@p.lodz.pl

Received: 13 July, 2005; revised: 25 July, 2005; accepted: 28 July, 2005

available on-line: 1 September, 2005

\begin{abstract}
Acetobacter xylinum strains are known as very efficient producers of bacterial cellulose which, due to its unique properties, has great application potential. One of the most important problems faced during cellulose synthesis by these bacteria is generation of cellulose non-producing cells, which can appear under submerged culture conditions. The reasons of this remain unknow. These studies have been undertaken to compare at the molecular level wild-type, cellulose producing $\left(\mathrm{Cel}^{+}\right)$A. xylinum strains with $\mathrm{Cel}^{-}$forms of cellulose-negative phenotype. Comparison of protein profiles of both forms of A. xylinum by 2D electrophoresis allowed for the isolation of proteins which were produced exclusively by either $\mathrm{Cel}^{+}$or $\mathrm{Cel}^{-}$cells. Sequences of peptides derived from these proteins were aligned with those of proteins deposited in databases. This analysis revealed that $\mathrm{Cel}^{-}$cells lacked two enzymes: phosphoglucomutase and glucose-1-phosphate uridylyltransferase, which generates UDP-glucose being the substrate for cellulose synthase. DNA was analyzed by ligation-mediated PCR carried out at low denaturation temperature (PCRMP). Two DNA fragments of different thermal stability (218 and $217 \mathrm{bp}$ ) were obtained from the DNA of $\mathrm{Cel}^{+}$and $\mathrm{Cel}^{-}$forms, respectively. The only difference between these $\mathrm{Cel}^{-}$and $\mathrm{Cel}^{+} \mathrm{DNA}$ fragments is deletion of one $\mathrm{T}$ residue. Alignment of those two sequences with those deposited in the GenBank database revealed that similar fragments are present in the genomes of some bacterial cellulose producers and are located downstream from open reading frames (ORF) encoding phosphoglucomutase. The meaning of this observation is discussed.
\end{abstract}

Keywords: bacterial cellulose, Acetobacter xylinum, 2-D electrophoresis, PCR-MP, phosphoglucomutase, UDP-glucose pyrophosphorylase

Bacterial cellulose has found multiple applications in various fields owing to its unique physicochemical and mechanical properties (Ring et al., 1986; Ross et al., 1991). However, the scale of its production, processing and use is relatively small because of problems with selection of sufficiently efficient producers and costs of culture media.

The most efficient producers of bacterial cellulose are the Gram-negative Acetobacter xylinum rods (reclassified as Gluconacetobacter xylinus) (Ya- mada, 2000). They occur singly, in pairs or in chains, reproduce by binary fission, are motile by flagella, and do not form endospores. Under limiting conditions, A. xylinum strains form involution forms, i.e. swollen or elongated filaments. Under conditions appropriate for bacterial growth these forms atrophy or fragment to shorter pieces which enables recovery of normal cells. The optimum temperature for A. xylinum growth is $25-30^{\circ} \mathrm{C}$, and optimum $\mathrm{pH}$ ranges from 5.4 to 6.2. A. xylinum produces cellu-

^Presented at the International Review Conference on Biotechnology, Vienna, Austria, November 2004.

Abbreviations: $\mathrm{Cel}^{+}$cells, wild-type cellulose-producing cells of Acetobacter xylinum; $\mathrm{Cel}^{-}$cells, non-reverting and cellulose-nonproducing forms of A. xylinum; c-di-GMP, cyclic di-guanosine monophosphate; CS, cellulose synthase; CTAB, cetyltrimethylammonium bromide; DTT, dithiothreitol; PCR-MP, ligation-mediated PCR performed at low denaturation temperatures; TAE, Tris/acetate/EDTA buffer. 
lose on the surface of liquid and solid culture media. Gelatinuous, leather-like mats formed on the surface of liquid culture media under stationary culture conditions contain bacterial cells entrapped in a network of cellulose fibers. Under agitated culture conditions, deposition of pellicle is disrupted and cellulose forms irregular granules stellate and fibrous strands (Bielecki et al., 2001). On agar media A. xylinum forms colonies with equal or undulate edges, transparent or white, smooth or rough, flat or convex.

A. xylinum strains are prone to spontaneous mutations yielding cellulose non-producing cells, which is one of the major problems facing commercial exploitation of bacterial cellulose biosynthesis. The appearance of $\mathrm{Cel}^{-}$forms in agitated cultures was first described by Schramm and Hestrin (1954) who isolated three different types of $A$. xylinum cells distinguished by morphology of colonies and efficiency of cellulose biosynthesis :

- Type I: wild-type, cellulose-producing $\left(\mathrm{Cel}^{+}\right)$cells;

- Type II: cellulose-nonproducing forms $\left(\mathrm{Cel}^{-}\right)$capable of reverting through passages;

- Type III: non-reverting cellulose-nonproducing forms $\left(\mathrm{Cel}^{-}\right)$.

The morphology of $\mathrm{Cel}^{+}$and $\mathrm{Cel}^{-}$colonies is different. Colonies of $\mathrm{Cel}^{-}$cells are rough, flat, slimy with undulate edges, in contrast to those of the $\mathrm{Cel}^{+}$type, which are spherical with smooth edges, gelatinous and convex.

The frequency of $\mathrm{Cel}^{+}$to $\mathrm{Cel}^{-}$conversion depends on culture conditions and their changes. Cellulose-producing cells dominate in stationary cultures and produce on the surface of culture medium a thick cellulose mat, called a pellicle, in which the embedded bacterial cells have contact with the oxygen-rich liquid/air interface. Sufficient and uniform aeration of liquid culture media under agitated culture conditions favors spontaneous appearance of $\mathrm{Cel}^{-}$cells, which become dominating in the population. Thus aeration of culture media is believed to be a factor against discriminating $\mathrm{Cel}^{+}$A. xylinum cells (Leisinger et al., 1966).

Studies on the effect of culture medium composition on the efficiency of cellulose synthesis under agitated culture conditions revealed that the highest yields of this biopolymer were achieved in media supplemented with ethanol $(2 \%, \mathrm{v} / \mathrm{v})$. According to Son et al. (2001) this phenomenon resulted not from a change in metabolism but from the lack of conversion of $\mathrm{Cel}^{+}$cells to $\mathrm{Cel}^{-}$ones. Hence, the spontaneous change of A. xylinum $\mathrm{Cel}^{+}$cells to the cellulosenegative phenotype in agitated cultures can be decreased by addition of ethanol to culture media (Son et al., 2001; Krystynowicz et al., 2002).

Cellulose synthesis by A. xylinum cells is catalyzed by four key enzymes:
- glucokinase (EC 2.7.1.2), responsible for phosphorylation on C-6 of glucose,

- phosphoglucomutase (EC 5.4.2.2), which catalyzes isomerization of glucose-6-phosphate to glucose-1-phosphate,

- glucose-1-phosphate uridylyltransferase (EC 2.7.7.9), which synthesizes UDP-glucose (UDPG),

- $\quad$ cellulose synthase (EC 2.4.1.12), which produces cellulose from UDP-glucose.

Glucose-1-phosphate uridylyltransferase (also known as UDPG pyrophosphorylase) is thought to play an important role in cellulose synthesis because the $\mathrm{Cel}^{-}$forms of $A$. xylinum lack this enzyme (Valla et al., 1989). However, the genetics and regulation of transcription of this enzyme in bacteria producing cellulose or related polysaccharides have not been explained.

According to Valla et al. (1987), also plasmids can be involved in cellulose biosynthesis. Based on electrophoretic separations of plasmid DNA isolated from A. xylinum it was found that nine of thirteen isolated mutants displayed changes in plasmid DNA profile as compared to the wild-type strain.

It was also reported that insertion elements could be involved in polysaccharide synthesis in Pseudomonas atlantica (Bartlett \& Silverman, 1989) and Xanthomonas campestris (Hotte et al., 1990). An unstable polysaccharide production by Zoogloea ramigera resulted from rearrangement of its DNA (Easson et al., 1987). The presence of insertion element IS1031 (950 bp) was detected in A. xylinum ATCC 23769. $\mathrm{Cel}^{-}$mutants of this strain possessed two or more IS1031 elements, and furthermore, their DNA was rearranged within the IS elements, as compared to cellulose-producing wild-type strain (Coucheron, 1991). Therefore, the loss of capability of some $A$. xylinum strains to produce cellulose is supposed to result from dislocation of insertion elements and inactivation of gene(s) responsible for cellulose synthesis.

The presented studies have been undertaken to compare wild A. xylinum $\mathrm{E}_{25}$ strain and $\mathrm{Cel}^{-}$forms possessing cellulose-negative phenotype at the molecular level. Genome DNA was isolated from $\mathrm{Cel}^{+}$ and $\mathrm{Cel}^{-}$A. xylinum $\mathrm{E}_{25}$ cells, and compared by PCRMP (PCR-melting profiles) analysis. Independently, protein profiles of both types of cells were compared by means of two-dimensional electrophoresis. Spots corresponding to the proteins inherent for only one type of the cells were excised from gels, digested and sequenced. The peptide sequences determined in this way were subsequently aligned with protein sequences deposited in databases. Two enzymes involved in the synthesis of various glucose-containing polysaccharides, namely phosphoglucomutase and glucose-1-phosphate uridylyltransferase, were identified as lacking in the $\mathrm{Cel}^{-}$phenotype. Possible reasons of this phenomenon are discussed. 


\section{MATERIALS AND METHODS}

Microorganism. A. xylinum $\mathrm{E}_{25}$ strain from the pure culture collection of the Institute of Technical Biochemistry of the Technical University of Lodz was used for the studies. It was maintained on agar slants at $4^{\circ} \mathrm{C}$.

Culture medium. The Schramm and Hestrin (1954) medium (SH medium), containing (g/l): glucose 20.0, yeast extract 5.0, bactopeptone 5.0, $\mathrm{Na}_{2} \mathrm{HPO}_{4}$ 2.7, citric acid 1.15, and $\mathrm{MgSO}_{4} \times 7 \mathrm{H}_{2} \mathrm{O}$ 5.7, with initial $\mathrm{pH}$ adjusted to 5.7 was used throughout the cultures.

Culture conditions. Inoculum was prepared by transferring a single $A$. xylinum $\mathrm{Cel}^{+}$or $\mathrm{Cel}^{-}$colony from $\mathrm{SH}$ agar medium into a 50-ml Erlenmeyer flask containing $10 \mathrm{ml}$ of liquid $\mathrm{SH}$ medium. This cell suspension $(10 \mathrm{ml})$ was added into a $500 \mathrm{ml}$ Erlenmeyer flask containing $100 \mathrm{ml}$ of a fresh $\mathrm{SH}$ medium. Agitated cultures were incubated at $30^{\circ} \mathrm{C}$ on a rotary shaker at 90 r.p.m.

Selection of non-reverting mutant. A non-reverting form of $A$. xylinum $\mathrm{E}_{25}$ was obtained by reiterated passages under agitated culture conditions. The cultures were carried out for $48 \mathrm{~h}$ at $30^{\circ} \mathrm{C}$ on a rotary shaker at 90 r.p.m. This process was repeated three times (3 passages). Cell suspension from each passage was spread on $\mathrm{SH}$ agar medium and incubated for 6 days at $30^{\circ} \mathrm{C}$. Colonies with morphology characteristic for $\mathrm{Cel}^{-}$forms were suspended in $5 \mathrm{ml}$ of liquid $\mathrm{SH}$ medium and incubated for 3 days at $30^{\circ} \mathrm{C}$ to test if the revertants were able to form the cellulose pellicle. Non-reverting forms were isolated from cellulose-free culture broths and used in further studies.

Sample preparation for 2D electrophoresis. A single colony of $\mathrm{Cel}^{+}$or $\mathrm{Cel}^{-} A$. xylinum $\mathrm{E}_{25}$ was suspended in $5 \mathrm{ml}$ of $\mathrm{SH}$ medium and incubated for $48 \mathrm{~h}$. From this culture, a $0.5 \mathrm{ml}$ inoculum was added do $10 \mathrm{ml}$ of $\mathrm{SH}$ medium (in a $50 \mathrm{ml}$ Erlenmayer flask) and incubated for $48 \mathrm{~h}$ at $30^{\circ} \mathrm{C}$. Bacterial cells were harvested by centrifugation (9000 r.p.m., $20 \mathrm{~min}, 4^{\circ} \mathrm{C}$ ), washed with $40 \mathrm{mM}$ Tris/ $\mathrm{HCl}$ and disrupted by sonication $(3 \times 2 \mathrm{~min})$. Proteins were separated using 2-D Clean-Up Kit (Amersham Biosciences) and suspended in a solution containing: 7 M urea, $2 \mathrm{M}$ thiourea, 4\% Chaps, 1\% DTT and 0.8\% ampholites $\mathrm{pH} 3-10$, according to Westemeier et al. (2002).

Two-dimensional gel electrophoresis. Twodimensional electrophoresis was carried out in an Ettan apparatus (Amersham Biosciences). In the first dimension the separation of proteins was based on their isoelectric points (Immobiline DryStrip gel $\mathrm{pH}$ $3-10)$, and in the second dimension the proteins were separated by SDS/PAGE gel $(12.5 \%, 200 \times 260$ $\mathrm{mm}$ ) according to the protocol of an Amersham Pharmacia Biotech Technical Manual (1999). The analyzed samples contained $75 \mu \mathrm{g}$ of proteins which were visualized by Silver Staining Kit (Sigma).

DNA isolation. DNA was isolated from $\mathrm{Cel}^{+}$ and $\mathrm{Cel}^{-}$cells of A. xylinum $\mathrm{E}_{25}$ according to Maniatis et al. (1989). Bacterial cells were pelleted by centrifugation $(1300 \times g$, $15 \mathrm{~min})$, washed with 10 $\mathrm{ml}$ TGE (25 mM Tris/ $\mathrm{HCl}, 50 \mathrm{mM}$ glucose, $10 \mathrm{mM}$ EDTA, $\mathrm{pH} 8)$ and again centrifuged $(1300 \times g, 15$ min). The pellet was suspended in $10 \mathrm{ml}$ TGE supplemented with lysozyme $(10 \mathrm{mg} / \mathrm{ml})$ and incubated at room temperature for $10 \mathrm{~min}$. Next, proteinase $\mathrm{K}$ $(100 \mu \mathrm{g} / \mathrm{ml})$ and $1 \%$ SDS were added and the mixture was kept at $37^{\circ} \mathrm{C}$ for $30 \mathrm{~min}$. Then, $2 \mathrm{ml}$ of 5 $\mathrm{M}$ aqueous $\mathrm{NaCl}$ solution and $1.5 \mathrm{ml}$ of $10 \% \mathrm{CTAB}$ in $0.7 \mathrm{M} \mathrm{NaCl}$ were added to the mixture, which was incubated at $65^{\circ} \mathrm{C}$ for $20 \mathrm{~min}$. After mixing with equal volume of phenol/chloroform, the mixture was centrifuged $(3600 \times g, 10 \mathrm{~min})$, extracted with a double volume of chloroform/isoamyl alcohol (24:1, v/v), carefully mixed with 2.5 volumes of cold $\left(-20^{\circ} \mathrm{C}\right)$ ethanol (96\%), and left for $15 \mathrm{~min}$. DNA was collected by centrifugation, the pellet washed 2 times with $70 \%$ ethanol, centrifuged at $3600 \times g$ for $10 \mathrm{~min}$ and dried.

PCR-MP (melting profiles). The PCR-MP procedure was carried out as described by Masny and Płucienniczak (2003). Bacterial DNA prepared as described above was digested with restriction endonuclease HindIII, extracted with phenol/chloroform, precipitated, the precipitate was dissolved in ligation mixture containing two oligonucleotide adapters: 5'-CTCACTCTCACCAACGTCGAA-3' (POWIH) and 5'-AGCTTTCGACGTTGG-3' (HIL) (20 pmol each), in a total volume of $20 \mu \mathrm{l}$ ligation buffer (66 mM Tris/HCl, pH 8.5, $6.6 \mathrm{mM} \mathrm{MgCl}_{2}$, $10 \mathrm{mM}$ DTT, $66 \mathrm{mM}$ ATP; Amersham Pharmacia Biotech). The mixture was heated in a water bath for $2 \mathrm{~min}$ at $56^{\circ} \mathrm{C}$ and cooled for $10 \mathrm{~min}$ at room temperature. Subsequently, $1 \mu \mathrm{l}$ of T4 DNA ligase $(1 \mathrm{U} / \mu \mathrm{l})$ was added and the samples were incubated overnight at $16^{\circ} \mathrm{C}$.

Then, PCR reaction was carried out in an MJ Research PTC200 thermocycler at denaturation temperatures $\left(\mathrm{T}_{d}\right) 80,81$ and $82^{\circ} \mathrm{C}$. The reaction mixture contained 50 pmol of POWBAGCT primer 5'-CTCACTCTCACCAACGTCGAAAGCTT-3', $100 \mu \mathrm{mol}$ each dNTPs and $1 \mu \mathrm{l}$ of ligation mixture in $50 \mu \mathrm{l}$ of PCR buffer. Samples $(8 \mu \mathrm{l}$ out of $50 \mu \mathrm{l})$ were loaded on $6 \%$ polyacrylamide gel (bisacrylamide/acrylamide $=1: 60$ ) with TAE buffer. The gel was stained with ethidine bromide and visualized in UV at $302 \mathrm{~nm}$, according to the protocol of Masny and Płucienniczak (2003). DNA fragments of different thermal stability were isolated from the gel (Dybczyński \& Plucienniczak, 1988), digested with HindIII restriction endonuclease, ligated with the pBluScriptSK $\mathrm{K}^{-}$plasmid (Stratagene) and cloned in Escherichia coli, strain NM522. The nucleotide sequences of the inserts were 
determined in the Institute of Biochemistry and Biophysics (PAS, Warsaw, Poland).

Protein identification. Proteins were identified by peptide mass fingerprinting using MALDITOF mass spectrometry and by partial peptide sequencing with ion trap electrospray mass spectrometry. Trypsin autodigestion peaks were exluded from the database searching. Molecular mass data were obtained from EXPASY (http://www.matrixscience. $\mathrm{com} /$ ). Monoisotopic peptide masses were used to search protein databases to match and subsequently identify individual protein spots.

\section{RESULTS}

\section{PCR-MP}

Figure 1 presents a profile of DNA fragments liberated by HindIII restrictase from the genomes under investigation and amplified at low $\mathrm{T}_{\mathrm{d}}$ 's according to the procedure described by Masny and Płucienniczak (2003). It appeared that in the case of the cellulose producer strain $\left(\mathrm{Cel}^{+}\right.$form) one of the DNA fragments migrating just above $242 \mathrm{bp}$ was less stable than the corresponding fragment from $\mathrm{Cel}^{-}$. The DNA fragment from $\mathrm{Cel}^{+}$cells was amplified at the denaturation temperature of $81^{\circ} \mathrm{C}$, while its counterpart from $\mathrm{Cel}^{-}$became visible when the $\mathrm{T}_{d}$ was $1^{\circ} \mathrm{C}$ higher. The less stable fragment (from $\mathrm{Cel}^{+}$cells) has a stretch of four T-residues (positions 76-79, Fig. 2), while its counterpart from $\mathrm{Cel}^{-}$contains at the same positions three $\mathrm{T}$ residues. One can suggest that the deletion of a single $\mathrm{T}$ residue in the $\mathrm{Cel}^{-}$fragment is responsible for its increased thermal stability as compared to that of the corresponding $\mathrm{Cel}^{+}$DNA fragment.

\section{Two-dimensional electrophoresis}

Figures $3 \mathrm{~A}$ and $3 \mathrm{~B}$ present intracellular proteins $(75 \mu \mathrm{g}$ per gel) isolated from the wild $A$. xylinum $\mathrm{E}_{25}\left(\mathrm{Cel}^{+}\right)$strain and its $\mathrm{Cel}^{-}$counterpart. Electrophoretic separation was carried out in the $\mathrm{pH}$ range from 4 to 7 in 12\% polyacrylamide gel. Proteins produced only by $\mathrm{Cel}^{+}$cells and not synthesized by the $\mathrm{Cel}^{-}$mutant, as well as proteins found only in $\mathrm{Cel}^{-}$mutant and lacking in wild-type strain are marked on the gels.

\section{Protein identification}

Proteins unique to $\mathrm{Cel}^{+}$or $\mathrm{Cel}^{-}$cells were excised from the gel and sequenced. The results of the analysis of peptides derived from intracellular $A$. $x y$ linum $\mathrm{E}_{25}\left(\mathrm{Cel}^{+}\right)$proteins supposedly involved in cellulose biosynthesis and missing in cells of the cellulose-nonproducing mutant are collected in Table 1.

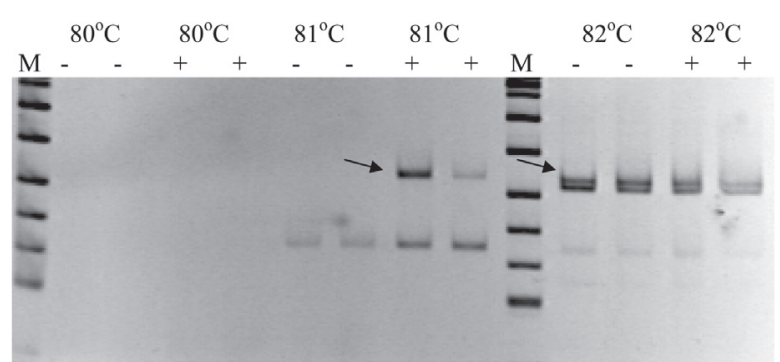

Figure 1. Electrophoretic pattern after PCR-MP of DNA preparations from $\mathrm{Cel}^{-}$and $\mathrm{Cel}^{+}$bacteria (lanes - and +, respectively).

Experiments for each temperature were repeated two times. $\mathrm{T}_{\mathrm{d}}$ 's of the PCR are marked above electrophoretic lines. DNA bands taken for cloning and nucleotide sequencing are marked with arrows. Lanes marked M, DNA markers: 110+111, 147, 190, 242, 331, 404, 476 and 489 base pairs.

These peptides are similar to amino-acid sequences of the following enzymes:

- phosphoglucomutase from: Gluconacetobacter xylinus, Mycobacterium tuberculosis (CDC1551), Bifidobacterium longum (NCC2705 and DJO10A), Streptomyces avermitilis (MA-4680), Pseudomonas fluorescens (PfO-1), Desulfovibrio vulgaris subsp. vulgaris str., and Leifsonia xyli subsp. xyli str. (CTCB07),

- glucose-1-phosphate uridylyltransferase from: Gluconacetobacter xylinus and Acetobacter pasteurianus.

\section{DISCUSSION}

Cellulose non-producing forms of $A$. xylinum were for the first time described in 1954 (Schramm \& Hestrin, 1954). An influence of culture conditions on the frequency of $\mathrm{Cel}^{-}$phenotypes (Leisinger et al., 1966; Son et al., 2001; Krystynowicz et al., 2002) and activities of enzymes involved in the synthesis of this polysaccharide (Valla et al., 1989) have been reported by several groups. An influence of plasmid DNA and insertion elements in the A. xylinum genome on the efficiency of cellulose synthesis was also described (Valla et al., 1987; Coucheron, 1991).

However, the reasons of the appearance of cellulose non-producing A. xylinum forms in agitated cultures remain obscure. One can suppose that this effect results from different expression of genes encoding enzymes responsible for glucose metabolism and/or cellulose synthesis. Wong et al. (1990) identified in A. xylinum the bcs operon encoding four proteins essential for bacterial cellulose synthesis. The first gene in this operon, $b c s A$, encodes the regulatory subunit of cellulose synthase (CS), which binds c-di-GMP acting as bacterial second messanger and activator in the cellulose synthesis process (Wong et $a l ., 1990)$. The second gene, $b c s B$, encodes the catalytic subunit of CS, which binds the substrate, UDP- 


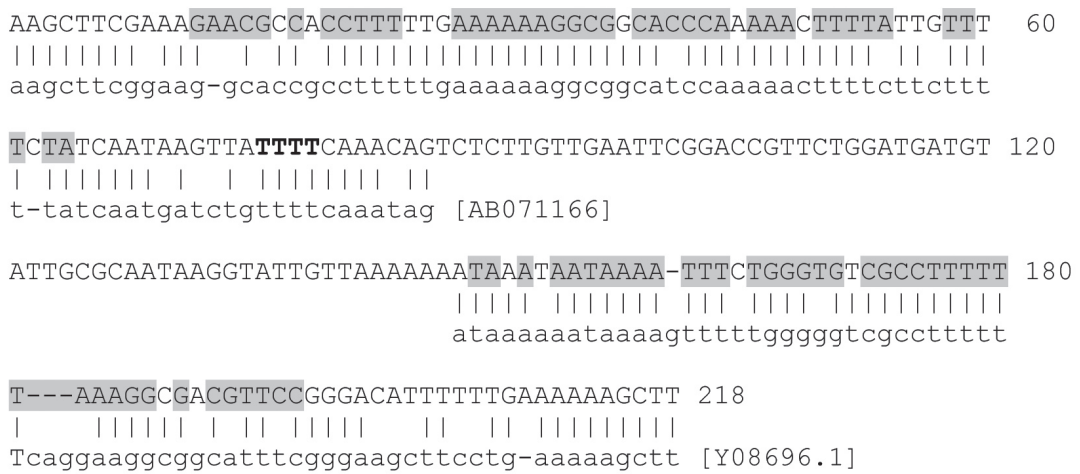

Figure 2. The nucleotide sequence of the $218 \mathrm{nt}$ element from $\mathrm{Cel}^{+} A$. xylinum $\mathrm{E}_{25}$ strain isolated after PCR-MP (shown in capital letters) and its comparison with the corresponding Gluconacetobacter xylinus and Acetobacter europaeus nucleotide sequences.

The array of $\mathrm{T}$ residues where deletion of one $\mathrm{T}$ occurs in $\mathrm{Cel}^{-}$is shown in bold. Inverted repeat sequences are shown by gray background. The GenBank accession numbers of the sequences under comparison are shown in square brackets.

glucose, and presumably catalyzes the polymerization of 1,4- $\beta$-D-glucan. Two other genes belonging to this operon, $d g c$ and $p d e A$, encode diguanylate cyclase and phosphodiesterase $\mathrm{A}$, which are respon-

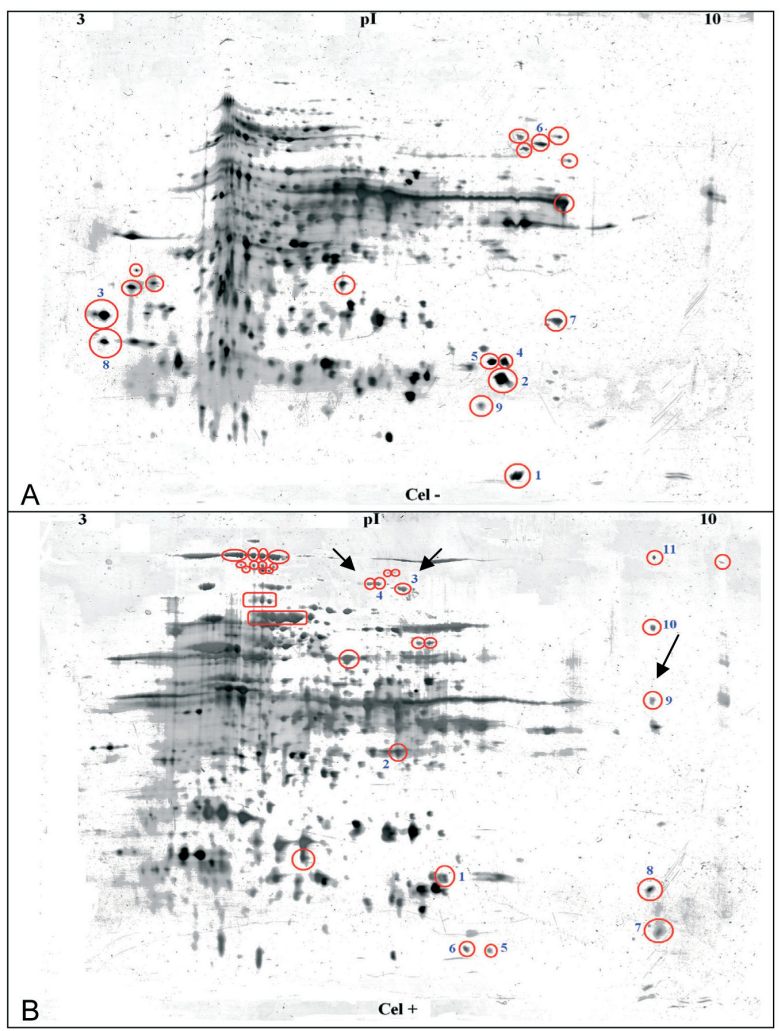

Figure 3. 2-D separation of a lysate of Acetobacter xylinum $\mathrm{E}_{25}$ cells.

Proteins from $\left(\mathrm{Cel}^{-}\right)(\mathrm{A})$ and wild-type $\left(\mathrm{Cel}^{+}\right)$(B) were separated by 2-D electrophoresis and visualized by silver staining. The $\mathrm{pH}$ gradient (horizontal direction) runs from $\mathrm{pH} 3-10$ and the SDS/PAGE separation (perpendicular direction) was performed in $12.5 \%$ gel. The arrows indicate the proteins identified as phosphoglucomutase (spots 3 and 4) and UDP-glucose pyrophosphorylase or glucose-1phosphate uridylyltransferase (spot 9). sible for the synthesis and degradation of c-di-GMP, respectively (Ross et al., 1991). Coucheron (1991) reported insertion of the IS1031 element upstream from the transcription start of this operon, which resulted in the deficiency of cellulose synthesis.

Our studies carried out with the use of the PCR-MP approach (Masny \& Płucienniczak, 2003) indicate that genomic libraries from $\mathrm{Cel}^{+}$and $\mathrm{Cel}^{-}$ strains contain DNA fragments of different thermal stability. In the case of the cellulose producer $\left(\mathrm{Cel}^{+}\right.$ form) a DNA fragment migrating just above $242 \mathrm{bp}$ is less stable than the corresponding fragment from $\mathrm{Cel}^{-}$cells. A comparison of their sequences has revealed that the thermally less stable fragment $\left(\mathrm{Cel}^{+}\right)$ has array of four T-residues (positions 76-79, Fig. 2), while its counterpart from $\mathrm{Cel}^{-}$cells contains at the same positions only three $\mathrm{T}$ residues.

Alignment of the $218 \mathrm{nt}$ sequence identified in our studies with those deposited in the GenBank database (National Center for Biotechnology Information) reveals that several genes of Acetobacter xylinum and Gluconacetobacter oxydans contain in their 3'-terminal parts (downstream from their ORFs) nucleotide sequences similar to the fragment sequenced in our studies. The 2,702,173 nt-long Gluconacetobacter oxydans genome contains five regions showing significant homology to this fragment (Table 4). However, it should be noticed that all these sequences are shorter than $218 \mathrm{nt}$ (see Fig. 2). Because the $218 \mathrm{nt}$ fragment contains inverted repeats (see Fig. 2), one can speculate that the corresponding RNA arising during transcription can form stem-loop or hairpin secondary structures (see Fig. 4). It is known that these types of RNA structures can regulate gene expression by their involvement in the transcriptional terminator/antiterminator mechanism (Turner et al., 1994; Yanofsky, 2000). It cannot be excluded that the loss of the single $\mathrm{T}$ residue results in a change of the RNA secondary structure which may influence transcription of the genes involved in cellulose synthesis. 
Table 1. Results of analysis of peptide fragments derived from gel slices numbered 3, 4 and 9 (according to Fig. 3).

\begin{tabular}{lll}
\hline Gel slice number 3 & Gel slice number 4 & Gel slice number 9 \\
\hline phosphoglucomutase (PGM) & phosphoglucomutase (PGM) & $\begin{array}{l}\text { glucose-1-phosphate uridylyltransferase } \\
\text { (UDPG) }\end{array}$ \\
amino acids: 555; & amino acids: 555; & amino acids: 284 \\
$M_{\mathrm{r}}: 59654$ & $M_{\mathrm{r}}: 59654$ & $M_{\mathrm{r}}: 31792$ \\
protein ID: P38569 & protein ID: P38569 & protein ID: P27897 \\
(swissprot); gil585669 & (swissprot); gil585669 & (swissprot); gi|7381245 \\
(according to NCBI) & (according to NCBI) & (according to NCBI) \\
score: 1394 & score: 1735 & score: 207 \\
queries matched: 36 & queries matched: 44 & queries matched: 5 \\
sequence coverage: $68 \%$ & sequence coverage: $76 \%$ & sequence coverage: $19 \%$ \\
\hline
\end{tabular}

Table 2. Localization of DNA fragments homologous to the $218 \mathrm{nt}$ element

\begin{tabular}{|c|c|c|c|c|}
\hline Bacterial strain & $\begin{array}{l}\text { GenBank } \\
\text { Accession Number } \\
\text { (literature reference) }\end{array}$ & $\begin{array}{l}\text { Region of } \\
\text { homology } \\
\text { within the } 218 \mathrm{nt} \\
\text { DNA } \\
\text { Element-coordi- } \\
\text { nates }\end{array}$ & $\begin{array}{l}\text { Region of } \\
\text { homology } \\
\text { in bacterial DNA, } \\
\text { data from } \\
\text { GenBank-coordi- } \\
\text { nates } \\
\end{array}$ & $\begin{array}{l}\text { Genes in the closest proximity to the } \\
\text { fragment homologous to the } 218 \mathrm{nt} \\
\text { element; (gene coordinates; name of } \\
\text { the protein; protein id) }\end{array}$ \\
\hline $\begin{array}{l}\text { Gluconacetobacter } \\
\text { xylinus b }\end{array}$ & $\begin{array}{l}\text { AB071166 } \\
\text { (Tajima et al., 2001) }\end{array}$ & $1-86$ & $716-799$ & 1137..3356; $\beta$-glucosidase \\
\hline $\begin{array}{l}\text { Gluconacetobacter } \\
\text { xylinus b }\end{array}$ & $\begin{array}{l}\text { AB091059 } \\
\text { (unpublished) }\end{array}$ & $1-86$ & $378-461$ & 808..3036; $\beta$-galactosidase \\
\hline $\begin{array}{l}\text { Acetobacter } x y- \\
\text { linum }\end{array}$ & $\begin{array}{l}\text { L24077.1 } \\
\text { (Brautaset et al., 1994) }\end{array}$ & $1-75$ & $1942-2012$ & 135..1812; phosphoglucomutase \\
\hline $\begin{array}{l}\text { Gluconobacter } \\
\text { oxydans } 621 \mathrm{H}\end{array}$ & $\begin{array}{l}\text { CP000009.1 } \\
\text { (Prust et al., 2005) }\end{array}$ & $56-1$ & $1137409-1137463$ & $\begin{array}{l}\text { 1136433..1137404; putative oxidore- } \\
\text { ductase; protein id: AAW60805.1 and } \\
\text { 1137522..1137968; hypothetical protein; } \\
\text { protein id: AAW60806.1 }\end{array}$ \\
\hline $\begin{array}{l}\text { Gluconobacter } \\
\text { oxydans } 621 \mathrm{H}\end{array}$ & $\begin{array}{l}\text { CP000009.1 } \\
\text { (Prust et al., 2005) }\end{array}$ & $154-208$ & $1137409-1137467$ & $\begin{array}{l}\text { 1136433..1137404; putative oxidore- } \\
\text { ductase; protein id: AAW60805.1 and } \\
\text { 1137522..1137968; hypothetical protein; } \\
\text { protein id: AAW60806.1 }\end{array}$ \\
\hline $\begin{array}{l}\text { Gluconobacter } \\
\text { oxydans } 621 \mathrm{H}\end{array}$ & $\begin{array}{l}\text { CP000009.1 } \\
\text { (Prust et al., 2005) }\end{array}$ & $1-56$ & $797775-797829$ & $\begin{array}{l}\text { 795730..797730; oligopeptidase; protein } \\
\text { id: AAW60504.1 and } 797839 . .798789 ; \\
\text { putative multidrug efflux pump; } \\
\text { protein id: AAW60505.1 }\end{array}$ \\
\hline $\begin{array}{l}\text { Gluconobacter } \\
\text { oxydans } 621 \mathrm{H}\end{array}$ & $\begin{array}{l}\text { CP000009.1 } \\
\text { (Prust et al., 2005) }\end{array}$ & $1-55$ & $916535-916588$ & $\begin{array}{l}\text { 915033..916508; NADPH-dependent } \\
\text { L-sorbose reductase; protein id: } \\
\text { AAW60623.1 and 916634..917890 (c); } \\
\text { UDP-N-acetylglucosamine 1-carboxy- } \\
\text { vinyltransferase; } \\
\text { protein id: AAW60624.1 }\end{array}$ \\
\hline $\begin{array}{l}\text { Gluconobacter } \\
\text { oxydans } 621 \mathrm{H}\end{array}$ & $\begin{array}{l}\text { CP000009.1 } \\
\text { (Prust et al., 2005) }\end{array}$ & $218-149$ & $916521-916594$ & $\begin{array}{l}\text { 915033..916508; NADPH-dependent } \\
\text { L-sorbose reductase; protein id: } \\
\text { AAW60623.1 and 916634..917890 (c); } \\
\text { UDP-N-acetylglucosamine 1-carboxy- } \\
\text { vinyltransferase; } \\
\text { protein id: AAW60624.1 }\end{array}$ \\
\hline $\begin{array}{l}\text { Acetobacter } x y- \\
\text { linus }\end{array}$ & $\begin{array}{l}\text { AB010645 } \\
\text { (Nakai et al., 1998) }\end{array}$ & $84-13$ & $16568-16638$ & $\begin{array}{l}\text { 12448..14655; } \beta \text {-glucosidase; } \\
\text { protein id: BAA31467.1 }\end{array}$ \\
\hline $\begin{array}{l}\text { Acetobacter } x y- \\
\text { linus }\end{array}$ & $\begin{array}{l}\text { AB010645 } \\
\text { (Nakai et al., 1998) }\end{array}$ & $1-60$ & $15344-15402$ & $\begin{array}{l}\text { 12448..14655; } \beta \text {-glucosidase; } \\
\text { protein id: BAA31467.1 }\end{array}$ \\
\hline $\begin{array}{l}\text { Acetobacter euro- } \\
\text { paens }\end{array}$ & $\begin{array}{l}\text { Y08696.1 } \\
\text { (Thurner et al., 1997) }\end{array}$ & $60-1$ & $5991-6049$ & $\begin{array}{l}\text { 3604..5925; aldehyde dehydrogenase; } \\
\text { protein id: BAA00408.1 }\end{array}$ \\
\hline $\begin{array}{l}\text { Acetobacter euro- } \\
\text { paens }\end{array}$ & $\begin{array}{l}\text { Y08696.1 } \\
\text { (Thurner et al., 1997) }\end{array}$ & $148-218$ & $5989-6062$ & $\begin{array}{l}\text { 3604..5925; aldehyde dehydrogenase; } \\
\text { protein id: BAA00408.1 }\end{array}$ \\
\hline $\begin{array}{l}\text { Acetobacter po- } \\
\text { lyoxogenes }\end{array}$ & $\begin{array}{l}\text { D00521.1 } \\
\text { (Tamaki et al., 1989) }\end{array}$ & $62-1$ & $2623-2683$ & $\begin{array}{l}\text { 236..2557; aldehyde dehydrogenase } \\
\text { precursor; protein id: BAA00408.1 }\end{array}$ \\
\hline $\begin{array}{l}\text { Acetobacter } x y- \\
\text { linum }\end{array}$ & $\begin{array}{l}\text { Y18467.1 } \\
\text { (Edwards et al., 1999) }\end{array}$ & $1-86$ & $1041-1123$ & $\begin{array}{l}\text { 32..997; glucosyl transferase; } \\
\text { protein id: CAB } 44443.1\end{array}$ \\
\hline
\end{tabular}


A comparison of the protein profiles of wildtype $\left(\mathrm{Cel}^{+}\right)$A. xylinum strains and their $\mathrm{Cel}^{-} \mathrm{mu}-$ tants revealed some differences. $\mathrm{Cel}^{-}$cells do not synthesize two key enzymes involved in cellulose biosynthesis, namely phosphoglucomutase and glucose-1-phosphate uridylyltransferase. The lack of glucose-1-phosphate uridylyltransferase in cellulose non-producing cells was reported earlier (Valla et al., 1989). Our studies proved that A. xylinum cells of $\mathrm{Cel}^{-}$phenotype are also deprived of phosphoglucomutase. Although it is known that phosphoglucomutase and glucose-1-phosphate uridylyltransferase (or UDP-glucose pyrophosphorylase) play a critical role in cellulose synthesis, their genetics and regulation have not been studied in detail.

Taking into account the results of the PCRMP analysis and 2D electrophoresis as well as the alignment of the nucleotide and peptide sequences, one can suggest that the cellulose deficiency in $A$. xylinum $\mathrm{Cel}^{-}$cells can result from the lack of expression of the genes encoding phosphoglucomutase and glucose-1-phosphate uridylyltransferase. Our finding that in the $\mathrm{Cel}^{-}$form the ORF encoding phosphoglucomutase may be flanked by a DNA fragment of a sequence different than that in $\mathrm{Cel}^{+}$cells can indicate a possible transcriptional repression of the gene expression.

\section{Acknowledgements}

This work was financially supported by grant No. 2 P04B 01726 from the State Committee for Scientific Research (KBN, Poland).

\section{REFERENCES}

Bielecki S, Krystynowicz A, Turkiewicz M, Kalinowska H (2005) Bacterial cellulose. In Biotechnology of Biopolymers, Steinbuchel A, Doi Y, eds, vol. 1, pp 381-434. Willey-VCH, Weinheim.

Bartlett DH, Silverman M (1989) Nucleotide sequences of IS492, a novel insertion sequences causing variation in extracellular polysaccharide production in the marine bacterium Pseudomonas atlantica. I Bacteriol 171: 1763 1766.

Brautaset T, Standal R, Fjaervik E, Valla S (1994) Nucleotide sequence and expression analysis of the Acetobacter xylinum phosphoglucomutase gene. Microbiology 140: $1183-1188$.

Coucheron DH (1991) An Acetobacter xylinum insertion sequence element associated with inactivation of cellulose production. J Bacteriol 173: 5723-5731.

Dybczyński I, Płucienniczak A (1988) A protocol for DNA fragment extraction from polyacrylamide gels. Biotechniques 6: 924-926.

Easson DD Jr, Sinskey AJ, Peoples OP (1987) Isolation of Zoogloea ramigera I-16 M exopolysaccharide biosynthetic genes and evidence for instability within this region. J Bacteriol 169: 4518-4524.

Edwards KJ, Jay AJ, Colquhoun IJ, Morris VJ, Gasson MJ, Griffin AM (1999) Generation of a novel polysaccharide by inactivation of the aceP gene from the acetan biosynthetic pathway in Acetobacter xylinum. Microbiology 145: 1499-1506.

Hotte B, Roth-Arnold I, Puhler A, Simon R (1990) Cloning and analysis of a $35.3 \mathrm{~kb}$ DNA region involved in exopolysaccharide production by Xanthomonas campestris. J Bacteriol 172: 2804-2807.

Krystynowicz A, Czaja W, Wiktorowska-Jezierska A, Goncalves-Miśkiewicz M, Turkiewicz M, Bielecki S (2002) Factors affecting the yield and properties of bacterial cellulose. J Ind Microbiol Biotechnol 29: 189-195.

Leisinger T, Wiemken A, Ettlinger L (1966) Über cellulosefreie Mutanten von Acetobacter xylinus. Arch Microbiol 54: 21-36.

Maniatis T, Sambrook J, Fritsch EF (1989) Molecular Cloning. A Laboratory Manual. 2 edn.

Masny A, Płucienniczak A (2003) Ligation mediated PCR performed at low denaturation temperatures - PCR melting profiles. Nucleic Acids Res 31: e114.

Nakai T, Moriya A, Tonouchi N, Tsuchida T, Yoshinaga F, Horinouchi S, Sone Y, Mori H, Sakai F, Hayashi T (1998) Control of expression by the cellulose synthase (bcsA) promoter region from Acetobacter xylinum BPR 2001. Gene 213: 93-100.

Protein Electrophoresis, Technical manual (1999) Amersham Pharmacia Biotech.

Prust C, Hoffmeister M, Liesegang $H$, Wiezer A, Fricke WF, Ehrenreich A, Gottschalk G, Deppenmeier U (2005) Complete genome sequence of the acetic acid bacterium Gluconobacter oxydans. Nat Biotechnol 23: 195-200.

Ring DF, Nashed W, Dow T (1986) Liquid loaded pad for medical applications. US Patent 45884000.

Ross P, Mayer R, Benziman M (1991) Cellulose biosynthesis and function in bacteria. Microbiol Rev 55: 35-58.

Schramm M, Hestrin S (1954) Factors affecting production of cellulose at the air/liquid interface of a culture of Acetobacter xylinum. J Gen Microbiol 11: 123-129.

Son HJ, Heo MS, Kim YG, Lee SJ (2001) Optimization of fermentation conditions for the production of bacterial cellulose by a newly isolated Acetobacter sp. A9 in shaking cultures. Biotechnol Appl Biochem 33: 1-5.

Tajima K, Nakajima K, Yamashita H, Shiba T, Munekata M, Takai M (2001) Cloning and sequencing of the betaglucosidase gene from Acetobacter xylinum ATCC 23769. DNA Res 8: 263-269.

Tamaki T, Horinouchi S, Fukaya M, Okumura H, Kawamura Y, Beppu T (1989) Nucleotide sequence of the membrane-bound aldehyde dehydrogenase gene from Acetobacter polyoxogenes. J Biochem (Tokyo) 106: 541544.

Thurner C, Vela C, Thony-Meyer L, Meile L, Teuber M (1997) Biochemical and genetic characterization of the acetaldehyde dehydrogenase complex from Acetobacter europaeus. Arch Microbiol 168: 81-91.

Turner RJ, Lu Y, Switzer RL (1994) Regulation of the Bacillus subtilis pyrimidine biosynthetic gene cluster by an autogenous transcriptional attenuation mechanism. J Bacteriol 176: 3708-3722.

Westemeier R, Naven T (2002) Proteomics in Practise. A Laboratory Manual of Proteome Analysis. Wiley-VCH.

Wong HC, Fear AL, Calhoon RD, Eichinger GH, Mayer R, Amikam D, Benziman M, Gelfand DH, Meade JH, Emerick AW, Bruner R, Ben-Bassat A, Tal R (1990) Genetic organization of the cellulose synthase operon in Acetobacter xylinum. Proc Natl Acad Sci USA 87: 81308134.

Valla S, Coucheron DH, Kjosbakken J (1987) The plasmids of Acetobacter xylinum and their interaction with the host chromosome. Mol Gen Genet 208: 76-83.

Valla S, Coucheron DH, Fjaervik E, Kjosbakken J, Weinhouse H, Ross P, Amikam D, Benziman M (1989) Clon- 
ing of a gene involved in cellulose biosynthesis in Acetobacter xylinum: complementation of cellulose-negative mutant by the UDPG pyrophosphorylase structural gene. Mol Gen Genet 217: 26-30.

Yamada Y (2000) Transfer of Acetobacter oboediens Sokollek et al. 1998 and Acetobacter intermedius Boesch et al.,
1998 to the genus Gluconacetobacter as Gluconacetobacter oboediens comb. nov. and Gluconacetobacter intermedius comb. nov. Int J Syst Evol Microbiol 50: 2225-2227.

Yanofsky C (2000) Transcription attenuation: once viewed as a novel regulatory strategy. J Bacteriol 182: 1-8. 